EDITORIAL

\title{
Improving Scholarship through Library Professionalism: an Inevitable Role of Librarianship in the World of Academia
}

\author{
T. Ramanan \\ Editor of JULA
}

\section{Introduction}

Library profession is being chiselled by ever-evolving digital era. Libraries and their services have been transformed over the past decades, due to the exponential growth and intricate nature of information resources and user demand. Having said that, information seekers largely depend on Google, thus the notion of alienating the library professionals appears to be quite serious.

Quoting Wilensky (1964, as cited by Freeman, 1997), dispute against the nature of any profession is universal across institutions, countries and time. Professions are progressive, static or backward on the line of the continuum of professionalization. In similar vein, librarians need to question themselves whether they are passionately committed to their profession. How far the librarians are scholars or proving to be intellectuals? Are librarians lifelong learners themselves and educating others to be lifelong learners?

As Germano (2011, as cited in Urquhart, 2015) states that physical visits of libraries has declined and library value deficit has become a problem. He further argues,

"Libraries cannot rely on the goodwill assumption that libraries are

a 'good thing'.... Along with their libraries, the perception of the librarians' worth also seems to be decreasing."

Therefore, academic librarians need to prove their worth through continuous skill development and library-faculty liaisons. As a result of that library professionalization will establish and sustain its existence in academic sphere. 
Besides, recognition of academic librarians in higher education institutions (HEIs) and UGC documents in Sri Lanka is often placed under argument. The denotation of the term 'Librarian' is either intentionally or accidentally omitted or distorted in authorizing documents. Furthermore, in certain universities in Sri Lanka, librarians are not equally treated in or invited to register their voices at official forums. However, the University Grants Commission of Great Britain (1921) had announced long ago that the library is the core organ of the university (Goonetillake, 1975 as cited in Jayasuriya, 2011).

Therefore, the professionalization of librarianship needs to address the development of scholarship both in academia/society and in librarians themselves. Elements of professionalization encapsulate lifelong learning and continuous professional development, along with other ethical considerations. This account sheds light on as to how university librarians are honing themselves as professionals, and the contribution of library code of professional ethics to professionalization. Within the library context, it also touches upon mechanisms to develop scholarship in society in general and academic and student communities in particular.

\section{Evolving Role of University Librarians}

On the verge of losing the recognition of status of librarians in Google Era, continuum of professionalization can only be progressive by transforming the service standards from traditional and reactive to current and proactive intervention. Self-driven learning and professional upgrading are mandatory to sustain the existence of librarians in higher education and research. Librarians are no longer confined to conventional library functions such as cataloguing and classification of books, rather they expand their responsibilities aligned with global electronic and educational revolution.

Zhang, Liu and Mathews (2015) argue that librarians' roles are more proactive and hybrid in the digital age. They continue that "libraries should demonstrate higher efficiency and effectiveness in the services by revamping organizational culture or structure to stimulate and realize more and deeper cross-boundary conversations and collaborations." In other words, librarians 
need to develop specific tools and services to meet the ever-changing research behaviour of scholars.

Since the role of librarians, in digital era, changes to emphasize more on serving the information seekers and researchers, library profession transcend the traditional boundaries in light of improving scholarship among faculty members (Mi, 2014). Therefore, academic librarians are compelled to inculcate themselves in terms of professionalism and academic calibre in order to satisfy the demand of teaching faculty members.

\section{Library Professionalism}

Professionalism is being defined by many scholars depending on the context, geography and time. When talking about (medical) professionals, Cogan (1953, as cited in Long, 1961) says,

"A profession is a vocation whose practice is founded upon an understanding of the theoretical structure of some department of learning or science, and upon the abilities accompanying such understanding. The profession, serving the vital needs of man, considers its first ethical imperative to be altruistic service to the client."

It is no different to the definition of professionalism of librarians; hence library professionals are required to develop their qualities and attitude, as long as they are bound to altruistic services to a wide range of communities.

Manasco and Jones (2002) hilariously record that conversation on professionalism does not have any issues whereas touching on professionalism of individuals exerts the undesired personality. In other words, they question about cognitive and attitudinal traits of professionalism when individuals are concerned. Larue and Severance (2000, as cited in Manasco \& Jones, 2002) say professionalism is all about attitude, which is reflected by cognition and conduct. Cognition and conduct is strongly associated with one's scholarship and ethics.

Improvement of intellectual tenacity of individuals and society is executed in more than one way by librarians. One is to manifest the professional and research qualities of librarians and other must be provoking scholarship in 
potential information seekers. Developing scholarship in society requires tremendous amount of intellectual capacity and versatility of librarians. Quoting Goonetillake (1975) as cited in Jayasuriya (2011), the university librarians need to think and act out of the box, thus their services would reach new and wider horizons. Hence, improvement of scholarship in academia is closely associated with librarians' professional capabilities.

Jayasuriya (2012) further states that role of librarians is mirrored by the behaviour expected of those professionals by society. Emphasis is given on cognition and conduct when the library occupants are expected to demonstrate qualities and calibre through professional etiquette and values, skills, and administration. She continues that in a world of specialized and interdisciplinary research the university librarians are compelled to adapt to changes in higher education and institutions.

Being academics, university librarians ought to engage themselves in selfmotivated, lifelong learning. As Bottazzo (2001) states, in the path of development and differentiation, library professionals need to absorb the changes whilst educating and training in individual fields of interests. Moreover, it is to observe how far library associations do assist the development of professionalism and social responsibility of librarians. Sri Lanka Library Association (SLLA) had developed and revised the Code of Professional Conduct and Ethics to improve self-awareness of professionalism among members and practice the occupation with social responsibility and ethics.

\section{Code of Professional Conduct and Ethics}

Like other service-oriented professions, librarianship too has its own code of conduct and professional ethics to streamline the operations. Library associations and national bodies in more than 60 countries had developed their own code of professional conduct and ethics. IFLA Governing Board had also constructed a similar document for international context (IFLA, March 14, 2016). 
Librarianship is strengthened by the formation of associations and professional conduct and ethics. Code of ethics of a profession not only ensures the quality of service but also makes the members (librarians) adhering to the values of the profession. These values reinforce the continuum of professionalization.

"....a code of ethics serves to promote the values of the profession over the personal, societal, and (sometimes) institutional values. It serves as a guideline for professionalism and quality of service... a description of the values of the profession which members must consider in order to act in a consistent and professional manner (Johnson, 2010).”

In this line, professional associations of librarians around the world and IFLA have drafted code of professional conduct and ethics to ensure the professional standards and values.

Librarians are required to observe highest standards in professional conduct, to perform their duties with honesty and integrity, and to cease from causing any disgrace to the profession. Elements of social responsibility of librarians as appeared in the code of professional conduct and ethics are emphasising on assurance of free access of information to user communities without any discrimination, whilst avoiding infringement of intellectual property rights (SLLA, 1998 \& 2015 rev.).

At this juncture, it is vital to scrutinize as to how far the members of library profession observe the values and standards through quality services and self-directed learning to strengthen the scholarship of user communities.

\section{Disputes of Librarianship and Facets of Scholarship}

Having faced with institution-bound challenges, the university librarians are in need to prove their worth by educating the users as well as themselves. University librarians in Sri Lanka had been avoided in many documents of UGC and respective universities, in which teaching faculties are mentioned for and have received certain privileges. In these occasions, the University Library Association (ULA, Sri Lanka) had to protest and fight the authorities 
to win the argument. Likewise, university librarians do not as equally have education and training as other teaching staff. Within the university itself, university librarians' involvement in important discussions such as curriculum development is not explicitly witnessed, although educationists continuously stress up on the inclusion of librarians in the curriculum development committees.

However, the question of as to what extent the academic librarians proactively register their professional capabilities and merits does exist on our mind. Dr. Pradeepa Wijetunge (personal communication, June 20, 2016) says that "we need more scholars as librarians." She further asks as to "what our (librarians') model of scholarship is, on what grounds we can call ourselves scholars or professors, and is there a difference between librarians' model of scholarship and the teachers' model of scholarship?" Dr. Wijetunge (personal communication, June 20, 2016) finds the most common answer, as she has heard, is that "because the (University) Act defines us so and may God help us if and when the (University) Act is revised." She observes an emphasis on teaching as the evidence of scholarship in the documents; nevertheless, she adds on that just by teaching for several hours an academic does not become a scholar.

Boyer's model of scholarship (Boyer, 1990) will remove the ambiguities built around the scholarship of university academics. In his model of scholarship, Boyer describes about four parts of becoming or defining a scholar in the realm of academia. Discovery, integration, application and teaching are those four parts in the model.

In the first part (discovery), one is engaged in primary research to contribute to the development of corpus of knowledge. Integration being the second part will involve critical analysis and review of knowledge, interdisciplinary collaboration, and scholarly synthesis of diverse views. Third part, scholarship of application or engagement, fills the gaps in existing knowledge, and resolves the issues in social needs and practice. Fourth part is scholarship of teaching where reflective analysis of knowledge of teaching and learning. 
In similar line, how librarians will demonstrate their scholarship in response to Google Era and interdisciplinary information demand from diverse user communities. Applying Boyer's four-part scholarship model to library professionalism, one can articulate the significance of research and publication in the field of library and information science. Every library professional is hereby required to explore their fields of interest. Using antiplagiarism tools librarians can ensure the quality of research dissemination across different domains.

Strengthening the library-faculty liaison will be promising only when librarians promote and execute interdisciplinary research in areas where creative synthesis and critical analysis of ideas are required. In the application part, librarians must fill the gaps in knowledge by engaging themselves in thematic and action research in order to resolve societal issues.

Information literacy programmes are valuable examples of scholarship of teaching in library context, which will lead to embedded librarianship and other faculty-library liaisons. Embedded librarianship presents a good opportunity for professional librarians to demonstrate and hone their teaching ability. Bosher (2009) narrates that first three domains of Boyer's scholarship model could be blended and used in teaching domain for dynamic education. Besides, four-part model does not constitute discrete domains but integrating and overlapping elements in the path of enriching the scholarship of academic library professionals.

\section{Summary}

In brief, the status of librarianship floats between prosperity and extinction. Firstly, the situation is intensified by the wave of digital information resources and tools. Second factor is internal, where two entities appear to be true. On the one hand, authorities and teaching academic staff knowingly or accidentally omit to recognize librarians as academics, on the other hand, librarians themselves need to think and act out of boxes. In this regard, continuum of professionalization is reinforced through the adherence of librarians to code of professional conduct and ethics. Meanwhile, librarians are required to manifest their scholarship in all senses in the world of academia, for which Boyer's scholarship model would be a guide. Four-part 
scholarship model will empower librarians to morph themselves in to dynamic scholars. To be recognized and competitive in academic culture, librarians need to be engaged in interdisciplinary research and corporate projects. Organized research in academia adheres to approved sets of methods and procedures by which new knowledge being produced are validated. Professional associations bear great responsibility in developing these research methods and procedures of academic publications. Therefore, being a member in such organization ensures and develops academic research skills in university librarians. It is always soothing to learn that findings of studies and words of eminent scholars around the world have declared the importance of library and information professionals in the abundance of information in this digital age. Will the library professionals substantiate the necessity of their existence through eternal scholarship and continuum of professionalization?

\section{References}

Bosher, R. (2009). Why is the Scholarship of Teaching and Learning such a hard sell? Higher Education Research and Development, 28(1), 1 15.

Bottazzo, V. (2001). New professions in librarianship, Library: Magazine for the field of library and information science, 45(4). Retrieved from http://revija-knjiznica.zbds-zveza.si/Izvodi/K0104/botazzo.pdf

Boyd, W.E. (2013). Does Boyer's integrated scholarship model work on the ground? An adaption of Boyer's model for scholarly professional development, International Journal for the Scholarship of Teaching and Learning, 7(2). DOI: http://dx.doi.org/10.20429/ijsotl.2013. 070225 .

Boyer, E. L. (1990). Scholarship reconsidered: Priorities of the professoriate. Washington, DC: Carnegie Foundation for the Advancement of Teaching. Retrieved from https://depts.washington.edu/gs630/ Spring/Boyer.pdf

Freeman, M. (1997). Is librarianship in the UK a true profession, a semiprofession or a mere occupation? New Library World, 98 (2), 65 69. DOI:http://dx.doi.org/10.1108/03 074809710159349 
Hamerly, D. \& Crowley, B. (2014). Sustaining professionalism in the field of library and information studies. Library Philosophy and Practice (ejournal). Retrieved from http://digital commons.unl.edu/ libphilprac/1231

IFLA (March 14, 2016). Professional codes of ethics for librarians. Retrieved from http://www.ifla.org/faife/professional-codes-of-ethics-forlibrarians

Jayasuriya, S. (2011). University library services in Sri Lanka: a historical perspective, Journal of the University Librarians' Association of Sri Lanka, 15 (1), 1 - 22. DOI: http://doi.org/10.4038/jula.v15i1.3187

Jayasuriya, S. (2012). Role of the university librarian: a review. Journal of the University Librarians Association of Sri Lanka, 16(2), 83 - 100. DOI: http://doi.org/10.4038/jula.v16i2.5201

Johnson, C. Neave (2010). The Importance of Professional Ethical Codes, LIS 600: Foundations of Library and Information Science, Spring 2006. Retrieved from https://sites.google.com/site/ charityneavejohnson/education/webfolio/foundations-1/importanceof-professional-ethics

Long, E. C. (1961). Professionalism in the library, the Southern Regional Group Meeting of the Medical Library Association, Austin, Texas, October 20- 21, 1961. Retrieved from http://www.ncbi.nlm.nih. gov/pmc/articles/PMC197813/pdf/mlab00191-0069.pdf

Manasco, J.E. \& Jones, R. F. (2002). Professionalism and Librarians, Library Faculty and Staff Publications. Paper 66. Retrieved from http://uknowledge. uky.edu/libraries_facpub/66

Mi, M. (2014). Expanding Librarian Roles through a Librarian Initiated and Facilitated Faculty Learning Community. Journal of Library Administration, 55 (1), 24 - 40. DOI: 10.1080/01930826.201 4.978683

SLLA (1998). Code of professional conduct and ethics. Colombo: Sri Lanka Library Association. Retrieved from http://www.ifla.org/files/assets/ faife/codesofethics/sri-lanka.pdf

SLLA (2015 rev.). Code of professional conduct and ethics. Colombo: Sri Lanka Library Association. 
Urquhart, C. (2015). Reflections on the value and impact of library and information services. Performance Measurement and Metrics, 16 (1), 86 - 102, DOI:http://dx.doi.org/10.1108/PMM-02-2015-0005

Zhang, Y., Liu, S., \& Mathews, E. (2015). Convergence of digital humanities and digital libraries, Library Management, 36 (4/5), 362 - 377. DOI: http://dx.doi.org/ 10.1108/LM-09-2014-0116 